\title{
Fifty Years of Sustainability Accounting: Does accounting for income in business sustainability really exist?
}

\author{
Dr. Mona ABOU TALEB* (Corresponding author) \\ UNE Business School - University of New England \\ Armidale, NSW 2351, Australia \\ E-mail: mabouta2@une.edu.au; mona-inp@hotmail.com
}

Prof. Brian Gibson

TOP Education Institute, Sydney

Garden Suburb, NSW 2289, Australia

Prof. Martin Hovey

UNE Business School - University of New England

Armidale, NSW 2351, Australia

Accepted: December 23, 2014

DOI: $10.5296 /$ ijafr.v5i1.6726

URL: http://dx.doi.org/10.5296/ ijafr.v5i1.6726

\begin{abstract}
The major challenges faced in the area of accounting for sustainability are the complexity and uncertainty of the subject matter, specially the lack of a clearly understood definition of sustainable development (SD). Further, the aspect of economic or income sustainability is one of the important measures of SD that can be achieved through the implementation of the concept of environmental management accounting (EMA). However, by taking an overview through the literature of accounting for business sustainability, the outcome of this paper indicates that the majority of literature on the financial or economic aspects of business sustainability focuses on the cost side and how to measure it either in monetary units or in non-monetary units while totally neglecting the revenue side either for business, environment, or society.
\end{abstract}

Keywords: Sustainable Development Accounting, Environmental Management Accounting, Income Sustainability Measurement, EMA Methodology.

\footnotetext{
* Dr. Mona ABOU TALEB is a Lecturer in Environmental Accounting Department, Center of Environmental Planning and Development, Institute of National Planning, Nasr City, Cairo, Egypt. Email: mona-inp@ hotmail.com
} 


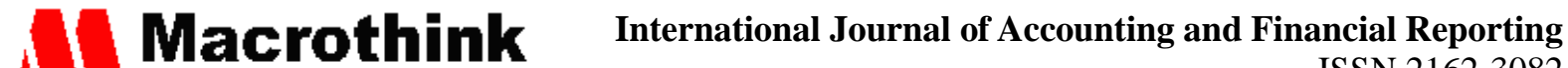 \\ ISSN 2162-3082 \\ 2015, Vol. 5, No. 1}

\section{Introduction}

One of the major challenges faced in the area of accounting for sustainability is the complexity and uncertainty of the subject matter, beginning with the lack of a clearly understood definition of sustainable development (hereafter SD) (Herath \& Gamini, 2005). In most of the literature, SD is defined as "integrating the economic, social and environmental objectives of society, in order to maximize human well-being in the present without compromising the ability of future generations to meet their needs" (Organization for Economic Cooperation and Development (OECD), 2001, p.11; Pyle \& Forrant, 2002, p.3).

Sustainability is a simple concept. "It is the capability of a corporate organization to add value and to continue to exist as an entity" (International Federation of Accountants (IFAC), 2006, p.3). Sustainable means capable of being sustained and sustainable development (of economic development or energy sources) means capable of being maintained at a steady level without exhausting natural resources or causing ecological damage (Collins-Ins, 2006).

"One of the most important purposes of accounting is to communicate relevant information to assist decision-makers. [The] quality [and type of] information enables them [decision-makers] to realize that they may adopt environmental prevention actions and at the same time decrease their overall costs and increase their profits" (Scavone, 2006, p.1278). The best related system that enables firms to generate this information is the environmental management accounting (hereafter EMA) system. IFAC's guideline (International Federation of Accountants (IFAC), 2005) broadly defines EMA as the identification, collection, analysis and use of two types of information for internal decision-making: Physical information on the use, flows, and fates of energy, water, and materials (including waste) and Monetary information on environment-related costs (including internal social costs), earnings and savings.

The definition spells out two important aspects of EMA, quantitative physical information (as in $\mathrm{kg}$, joules, meters, lbs, etc) and monetary information. Thus, the EMA methodology can be applied to identify different environmental/social impacts in monetary terms. It helps express the results in the "language" of the managers.

Conventionally, SD is described in three dimensions: social, environmental and economic. However, these dimensions are not separable, but strongly influence each other. Most organizations have an interest in SD as well as their need to generate financial or economic benefit, thus, organizations should deal with social and environmental issues as part of ensuring that they generate added value for an organization and its stakeholders (International Federation of Accountants (IFAC), 2006). From the perspective of the quality of human life, three dimensions could be considered: economic, ecological, and social (human). From this perspective, the economic criteria could focus on the maintenance of a constant stream of income. This aspect of economic or income sustainability is one of the important measures of SD that can be achieved through the implementation of the concept of EMA, however, it is still ignored and typically not mentioned in the literature.

The concept of SD requires an integrated assessment of the economic, social and 


\section{MInstitute Machink $_{\text {Ins }}$}

environmental aspects of organizational activities. Depending on the degree of this integration in organization strategy, companies' SD could be classified into three types: compliance, 'do no harm', and sustainable (see figure 1). Compliance is the minimum and means that companies should comply with national regulations and internationally agreed law. 'Do no harm' is beyond basic compliance; companies should be aware of their ability to create real and potential socio-economic and environmental impacts (Hitchcock \& Willard, 2006). Building on this awareness, they should develop and implement policies and procedures to minimize any damage that may result from their own business operations, for example applying ISO 14001 and EMA. However, sustainable is beyond compliance and 'do no harm', i.e., companies can proactively contribute to national sustainability by engaging in innovative social investment, stakeholder consultation, policy dialogue, advocacy and civic institution building, ideally through collective action with other companies (Hitchcock \& Willard, 2006).

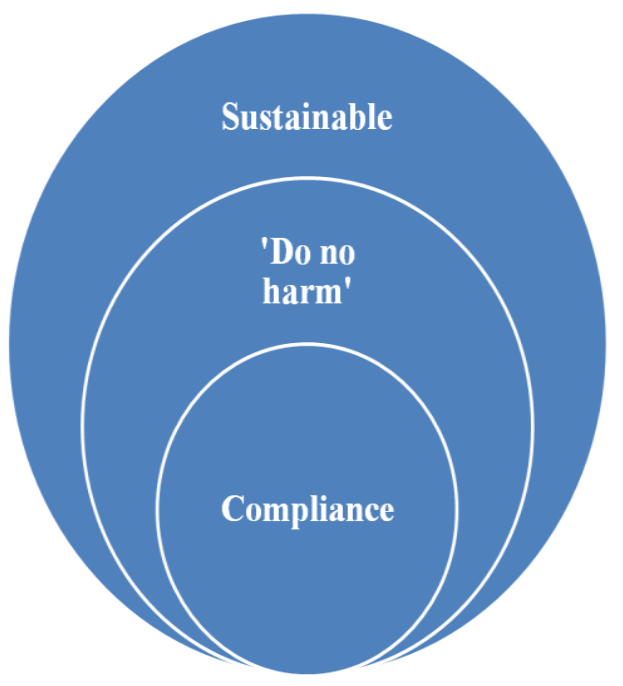

Figure 1: Types of companies' sustainability.

Source: Modified from Hitchcock and Willard 2006.

EMA is a tool that assists organizations in becoming more sustainable by highlighting overall costs, risks, incomes and benefits associated with all organization activities either related to production or not. It extends traditional financial and cost accounting to take account of sustainability impacts at the organizational level. As sustainability is based on a broad stakeholder approach, the external effects of the organization and its products must also be considered. The focus of EMA is on extending the range of monetized information (covering environmental, social and economic impacts) on which decisions are made (Jasch \& Lavicka, 2006). EMA brings an emphasis to the external effects pertaining to organization activities so they can be considered in internal decision-making. That means data of financial and cost accounting are analyzed to consider environmentally related issues (e.g. material and energy inputs and outputs, costs for environmental management) and social aspects (e.g. costs of employee's illness, costs of labor fluctuation). The third dimension of sustainability, the 


\section{MInstitute Macrothink $_{\text {Ins }}$}

economic dimension of the company's wealth, is accomplished by rearranging the profit-loss statement into a value added calculation. In addition, intangible values, risk aspects and external effects (such as reduction in the number and cost of external complaints due to company's tree planting activities) of organization activities are considered.

As organizations become more complex, decentralized and at the same time exposed to increased demands for environmental protection and corporate social responsibility, the need for measuring and evaluating the effect of SD aspects for organizations by accounting tools and the necessity of defining clearer concepts and appropriate strategies for sustainability are increasing.

In this article the term EMA will be used to reflect both environmental and social aspects of business as well as financial aspect as a main sustainability accounting system to reach business sustainability. Thus, this article will scan the accounting literature concerning sustainability accounting to investigate the variety of accounting tools applied to achieve business sustainability and whether there is a bias in the literature toward the cost side of sustainability. 


\section{Macrothink \\ International Journal of Accounting and Financial Reporting \\ ISSN 2162-3082 \\ 2015, Vol. 5, No. 1}

\section{An Overview through the Literature}

The literature of SD accounting is generally split into two branches; green national accounting and corporate environmental accounting.

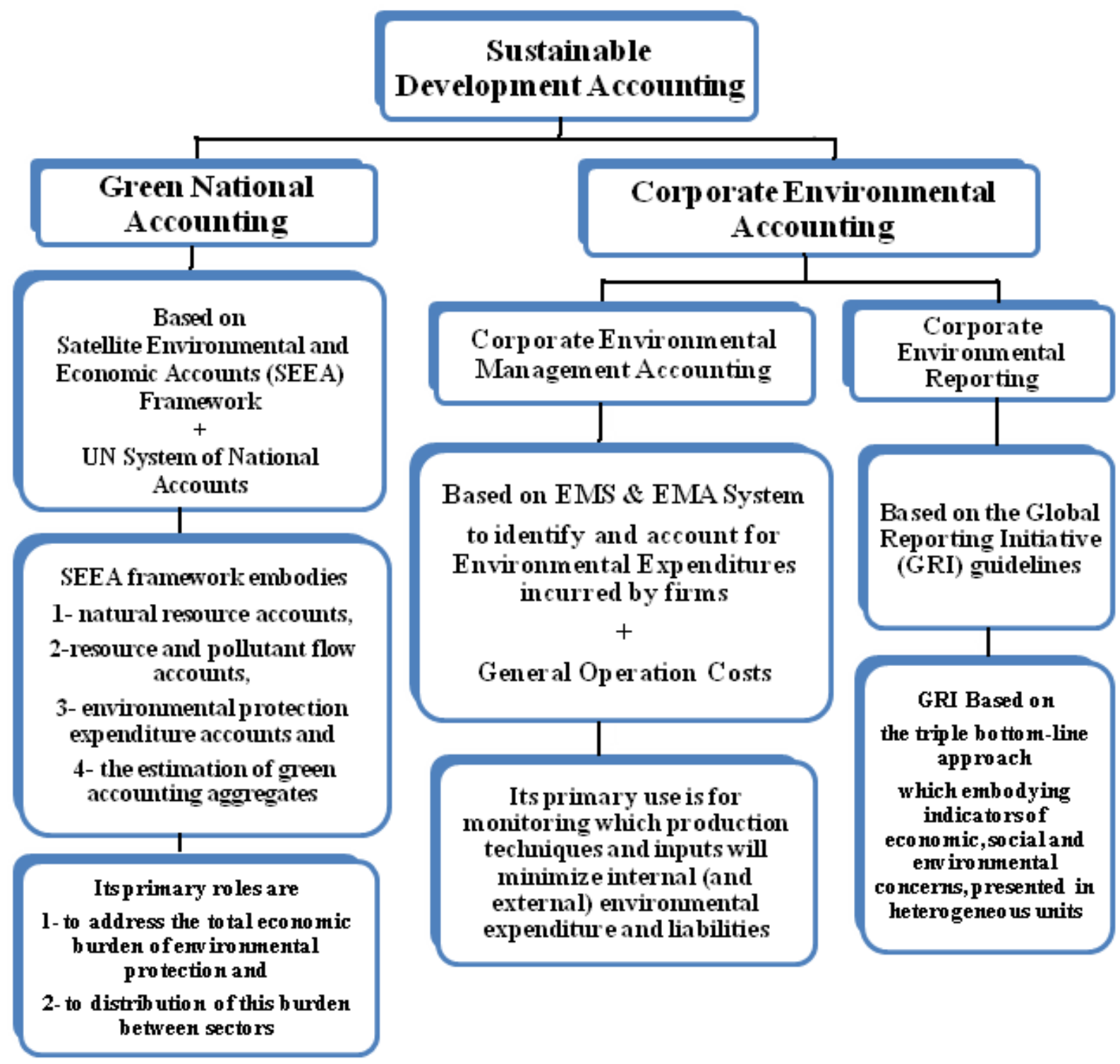

Figure 2: The literature of SD accounting.

Source: Combined from literature below.

Green national accounting is based on the Satellite Environmental and Economic Accounts (SEEA) Framework in addition to the UN System of National Accounts (Bartelmus, 2007; de Haan \& Kee, 2003; Kee \& de Haan, 2003; Stevens, 2005) The SEEA framework embodies: natural resource accounts, resource and pollutant flow accounts, environmental protection expenditure accounts and the estimation of green accounting aggregates. Its primary roles are 


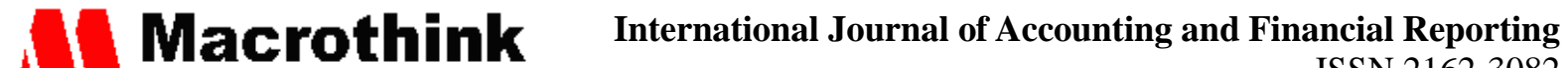 \\ ISSN 2162-3082 \\ 2015, Vol. 5, No. 1}

to address the total economic burden of environmental protection and the distribution of this burden between sectors (Bartelmus, 2007; Kee \& de Haan, 2003).

On the other side, corporate environmental accounting involve two branches; corporate environmental management accounting which is the focus area in this research and corporate environmental reporting. Corporate environmental management accounting is based on environmental management system (EMS) and EMA system to identify and account for environmental expenditures incurred by firms adding to general operation costs. Its primary use is for monitoring which production techniques and inputs will minimize internal and external environmental expenditure and liabilities (Deegan, 2003; C. Jasch \& Stasiškienè, 2005; United Nations Division for Sustainable Development, 2001). Corporate environmental reporting however is based on the GRI guidelines which are the widely adapted framework for corporate environmental reporting. GRI guidelines are based on the triple bottom-line approach (GRI, 2007) which embody indicators of economic, social and environmental concerns, presented in heterogeneous units.

There is clearly a growing interest among academics in the issues of sustainable accountancy and decision-making, as reflected in the growing volume of literature dedicated to these issues (Bartelmus, 1992; Bebbington, 2001; Bebbington, Brown, \& Frame, 2007; Brown \& Dillard, 2013; Birkin, Edwards, \& Woodward, 2005; Gray, 1992; Lamberton, 2005; Schaltegger \& Burritt, 2006; Taplin, Bent, \& Aeron-Thomas, 2006; Thomson, Grubnic, \& Georgakopoulos, 2014). This is complemented by organizations' increased awareness of the importance of sustainable business practices which are based on the business life cycle performance as a tool to assess the business SD. There is also a growing understanding that accountants have an important role to play, demonstrated by the work that is being done by the leading accountancy bodies (such as: The Association of Chartered Certified Accountants (ACCA), the Chartered Institute of Management Accountants (CIMA), The Institute of Chartered Accountants in England and Wales (ICAEW), The Fédération des Experts Comptables Européens (FEE), The Chartered Institute of Public Finance and Accountancy (CIPFA), The International Federation of Accountants (IFAC)) to engage the profession in sustainability issues (Accounting for Sustainability Group, 2006).

However, despite this growing profile and the variety of possible approaches to accounting for sustainability and many EMA tools implemented in academic and practice work to reach sustainability, there is an obvious bias toward the cost side of business sustainability (Antheaume, 2007; Bebbington, et al., 2007; Bebbington \& Larrinaga, 2014; Birkin, 2000; Gray, 1992; Herbohn, 2005; Lamberton, 2000; Nichols, 2012; Yang, 2007) rather than the revenue side. In other words, the majority of business sustainability literature emphasis is on measuring and reporting the sustainability costs (financial, environmental and social) either in monetary units or in non-monetary units while totally neglecting the revenues either for business, environment, or society.

This focus on costs is highlighted in the following reverse chronological summary of sustainability accounting literature and some of EMA tools applied to achieve business sustainability: 


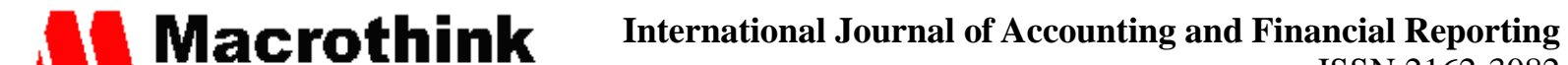 \\ ISSN 2162-3082 \\ 2015, Vol. 5, No. 1}

Full Cost Accounting (FCA) is an accounting technique (as a synonym to EMA) gaining popularity in determining monetary values (mainly costs) within policy and business circles. For example, Bebbington and Larrinaga (2014) used FCA to assign a value to the use of externalities; free environmental (and social) services. While, Bebbington (2007) applied the Sustainability Assessment Model (SAM) which is a form of FCA as an environmental accounting tool to provide insights into the interrelationship between existing management accounting practices and accounting tools which seek to guide organizations towards SD and create information about accounting techniques which addresses the issue of SD. The current limitations of both techniques are their concentration on measuring all types of costs through extended business life cycle with a limited focus on incomes and profits measurements from environmental and social sources, however, the ability to develop and find a chance to reach comprehensive financial position of a business including environmental and social factors.

Yang (2007) used Life Cycle Assessment (LCA) to integrate the sustainability into the product design and development process. His approach (i.e. eco-design) was established on a methodological framework consisting of life cycle sustainability metrics, inventory databases for sustainability calculations, and design support tools. The eco-design approach and its supported tools permit designers and engineers to calculate and compare material and energy consumptions, and to estimate environmental impacts of numerous end-of-life (EoL) treatment solutions in physical units. The limitation in this article is that the main focus on non-monetary information rather than monetary information. In addition non-monetary information can be used as non-financial information inputs into EMA system to support mainly the cost side of sustainability with obvious neglecting for income and profitability matter.

Also in use is the environmentally balanced scorecard which is an internal reporting or communication method applied to cleaner production and EMA programs to communicate primarily the integrated performance of companies from both a monetary and non-monetary perspective. Scavone (2006), for example, integrated his data through a set of indicators organized according to an environmentally balanced scorecard methodology to provide important information for decision-makers and add real value to SD by assisting users to become conscious of sustainability-related matters. However, the superiority of this method in illustrating and bringing the sustainability interrelated dimensions into one place, it is still unable to provide clear measures for income sustainability.

Gray (2001) briefly outlines what he believed are the three pillars (strands) of social accounting. As a conclusion, he has listed a few key lessons that everyone should learn and retain from the thirty-years of social accounting. They are the use of silent social accounts, voluntary social reporting, availability of systematic social accounts and the ability to monitor and respond to social changes which is highly needed. This article outlines only one dimension of accounting for sustainability (i.e. social accounting) based on stakeholder model which focus mainly on non-monetary information (such as: number and types of employees, compliance with industry codes, and compliance with the organization's own mission/value statement) with full overlooked measure of how these information are accounted for either in the form of costs or revenues. 


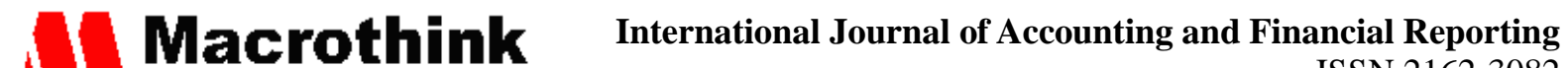 \\ ISSN 2162-3082 \\ 2015, Vol. 5, No. 1}

The life cycle environmental cost analysis (LCECA) model that included eco-costs into the total cost of the products was discussed by Kumaran, et al. (2001). The article associated eco-costs and both direct and indirect costs of the environmental impact attributable to the product in its whole life cycle. How the LCECA model could be used to identify the feasible alternatives for cost-effective, eco-friendly parts/products also are described. This attempts to incorporate costing into the life cycle assessment (LCA) practice, which is a systematic assessment of the requirements (needs) and possibilities (opportunities) to reduce the environmental burdens associated with energy and raw material use, and waste emissions throughout the life cycle of a product, process or activity. LCECA model as an EMA tool ignores in an obvious way the income side of environmental accounting as one of the branches of accounting for sustainable. This negligent appears in the main concentricity on the costs information (monetary and non-monetary) into the product life cycle.

Letmathe and Doost (2000) tried to illustrate how to utilize an environmental cost accounting system for internal and external audits and performance improvements. They also briefly discussed about five steps to reduce environmental costs particularly: setup EMS system to identify significant cause and environmental impacts (input related, process-caused and product-cause environmental impacts); determine the flow cause of significant impacts; quantify the material and energy; evaluate their realistic costs; and determine the causing objects correctly. This article mainly concerned about the monetary and non-monetary information for cost side of sustainability (mainly environmental cost) without mentioning for profitability or income part.

A substantial number of environmental standards, laws and regulations, which have been introduced to hold businesses accountable for their environmental responsibilities was discussed by Nichols (2012) and Rezaee and Elam (2000). Presently, there are two significant types of environmental accountability which have social and financial consequences; mandatory requirements where the corporations must comply with applicable accounting standards and governmental laws and regulations, and voluntary initiatives as an integral part of social responsibilities and both types have clear focus on the cost side of sustainability, however, the effect of these laws and regulations neither on the cost hand nor on the income side are discussed. Rezaee and Elam (2000) article also presented a step-by step implementation plan to adopt adequate and effective environmental management system, perform proper environmental audits, and successfully become registered to ISO 14001.

The early corporate governance and accountability over the reporting and disclosure of environmental cost and their obligations are outlined by Rezaee, Szendi and Aggarwa (1995). The legislative efforts through the USA Environmental Protection Agency (EPA) relating to environmental issues are typically directed towards control of contamination; clean up of contaminants, environmental hazards in the workplace, injury to public health and recovery of damages. This article focus on reporting and disclosing monetary and non-monetary information for cost dimension of sustainability (including environmental and some limited social aspects) without paying any attention to income side, profitability or sustainable financial position. 


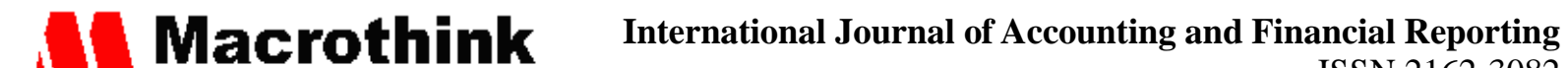 \\ ISSN 2162-3082 \\ 2015, Vol. 5, No. 1}

Gray (1992) initially uses the idea of a sustainable cost calculation (SCC) to construct an "account of sustainability". SCC attempts to

"derive a parallel accounting system which provides calculations of what additional costs must be borne by the organization if the organizational activity were not to leave the planet worse off, i.e. what it would cost at the end of the accounting period to return the planet and biosphere to the point it was at the beginning of the accounting period" (Gray, 1992,p.419).

SCC is more modest than a full scale tracking of all inter-capital flows. Thus the SCC aims to determine the estimated costs of restoring the environment to its previous condition using conventional accounting concepts on a year by year basis. It is clearly that SCC is neither a sustainable income concern nor about full sustainability (an examination of an organizations impact on human-made capital, for example, is not tackled).

\section{Conclusion}

As EMA systems in business have evolved over time, interest has grown in developing a better understanding of environmental and social-related financial costs and benefits as input to conventional management accounting. However, the literature indicates growing evidence that focuses on environmental/social accounting related tools to enhance the cost measurements rather than the income, profitability and financial position of a business that are related to environmental/social factors.

Generally, environmental/social accounting for business sustainability is used to assess full environmental/ social costs associated with activities and/or products (environmental social and financial). Environmental/social accounting also can be used to track environmental/ social performance of organizations' in more measurable manner.

We argue that the income side of business sustainability performance is totally neglected or at best it is measured as a byproduct. For example, there is a clear and recognized classification for companies' environmental costs published by EPA, while there is not one for environmental incomes. Environmental costs published by EPA include: conventional costs such as materials, labor, and utilities, as well as potentially hidden (these costs are typically assigned to overhead accounts), and less tangible costs (costs that may be more difficult to measure because they are contingent, e.g., potential future liability, or are difficult to quantify, e.g., corporate image) (United States Environmental Protection Agency (USEPA), 1995).

We argue that the social and environmental accounting literature has paid very little attention to either organizational influences on its practice, or the impact of the practice of social and environmental accounting on organizations and their participants. Research into sustainability accounting mainly social and environmental accounting and its related management accounting systems has also paid little attention to assessing sustainability incomes that related to companies' social and environmental activities.

\section{References}

Accounting for Sustainability Group. (2006). Accounting for Sustainability: A Review of Academic Literature: ASG. HRH The Prince. 
Antheaume, N. (2007). Full cost accounting: Adam Smith meets Rachel Carson? In J. Unerman, J. Bebbington \& B. O’Dwyer (Eds.), Sustainability accounting and accountability. London: Routledge.

Bartelmus, P. (1992). Accounting for sustainable growth and development. Structural Change and Economic Dynamics, 3(2), 241-260.

Bartelmus, P. (2007). SEEA-2003: Accounting for sustainable development? Ecological Economics, 61(4), 613-616.

Bebbington, J. (2001). Sustainable development: A review of the international development, business and accounting literature. Accounting Forum, 25(2), 128-157.

Bebbington, J. (Ed.). (2007). Accounting for Sustainable Development Performance. London: Elsevier Ltd.

Bebbington, J., Brown, J., \& Frame, B. (2007). Accounting technologies and sustainability assessment models. Ecological Economics, 61(2-3), 224-236.

Bebbington, J., \& Larrinaga, C. (2014) Accounting and sustainable development: An exploration. Accounting, Organizations and Society 39(6), 395-413.

Birkin, F. (2000). The art of accounting for science:Aprerequisite for sustainable development? Critical Perspectives on Accounting, 11(3), 289-309.

Birkin, F., Edwards, P., \& Woodward, D. (2005). Accounting's contribution to a conscious cultural evolution: An end to sustainable development. Critical Perspectives on Accounting, 16(3), 185-208.

Brown, J., \& Dillard, J. (2013). Agonizing over engagement: SEA and the "death of environmentalism' debates. Critical Perspectives on Accounting, 24(1), 1-18.

Collins-Ins. (Ed.) (2006). ( $2^{\text {nd }}$ ed.). Harper Collins Publishers.

de Haan, M., \& Kee, P. (2003). Accounting for Sustainable Development: The NAMEA-Based Approach. Netherlands.: Division of Macro-economic Statistics and Dissemination Development; Statistics Netherlands.

Deegan, C. (2003). Environmental Management Accounting: An Introduction and Case Studies for Australia. Melbourne: Environment Protection Authority of Victoria (EPA Victoria) \& Institute of Chartered Accountants in Australia.

Gray, R. (1992). Accounting and environmentalism: An exploration of the challenge of gently accounting for accountability, transparency and sustainability. Accounting, Organizations and Society, 17(5), 399-425.

Gray, R. (2001). Thirty years of social accounting, reporting and auditing: what (if anything) have we learnt? Business Ethics: A European Review, 10(1), 9-15.

GRI. (2007). Sustainability Reporting 10 Years On. Netherlands: Global Reporting Initiative.

Herath, \& Gamini. (2005). Sustainable development and environmental accounting: The challenge to the economics and accounting profession. International Journal of Social Economics., 32(12), 1035-1050.

Herbohn, K. (2005). A full cost environmental accounting experiment. Accounting Organizations and Society, 30(6), 519-536.

Hitchcock, D., \& Willard, M. (2006). The Business Guide to Sustainability. London : United Kingdom.: Earthscan Press. 
International Federation of Accountants (IFAC). (2005). International Guidelines on Environmental Management Accounting: International Federation of Accountants.

International Federation of Accountants (IFAC). (2006). Professional Accountants in Business:At the Heart of Sustainability? : IFAC. Information Paper. Professional Accountants in Business Committee.

Jasch, \& Lavicka, A. (2006). Pilot project on sustainability management accounting with the Styrian automobile cluster. Journal of Cleaner Production, 14, 1214-1227.

Jasch, C., \& Stasiškienè, Ž. (2005). From environmental management accounting to sustainability management accounting. Environmental Research, Engineering and Management, 34(4), 77-88.

Kee, P., \& de Haan, M. (2003). Accounting for Sustainable Development. Netherlands: Division of Macro-economic Statistics and Dissemination Development; Statistics Netherlands.

Kumaran, D. S., Ong, S. K., Reginald Tan, B. H., \& Nee, A. Y. C. (2001). Environmental life cycle cost analysis of products. Environmental Management and Health, 12(3), 260-276.

Lamberton, G. (2000). Accounting for sustainable development-A case study of city farm. Critical Perspectives on Accounting, 11(5), 583-605.

Lamberton, G. (2005). Sustainability accounting: a brief history and conceptual framework. Accounting Forum (Adelaide), 29(1), 7-26.

Letmathe, P., \& Doost, R. K. (2000). Environmental cost accounting and auditing. Managerial Auditing Journal, 15(8), 424-430.

Nichols, L.M. (2012). Has international oil and gas accounting been politicized? Petroleum Accounting and Financial Management Journal, 31(1), 22-34.

Organization for Economic Cooperation and Development (OECD). (2001). Strategies for Sustainable Development: Practical Guidance for Development Co-operation.: OECD.

Pyle, J. L., \& Forrant, R. (2002). Globalization, Universities Sustainable Human Development: A Framework for Understanding The Issues. In Jean L. Pyle \& Robert Forrant (Eds.), Globalization, Universities and Issues of Sustainable Human Development (pp. 3-28). Massachusetts, USA: Edward Elgar Publishing, Inc.

Rezaee, Z., \& Elam, R. (2000). Emerging ISO 14000 environmental standards: a step-by-step implementation guide. Managerial Auditing Journal, 15(1), 60-67.

Rezaee, Z., Szendi, J. Z., \& Aggarwal, R. (1995). Corporate governance and accountability for environmental concerns. Managerial Auditing Journal, 10(8), 27-33.

Scavone, G. M. (2006). Challenges in internal environmental management reporting in Argentina. Journal of Cleaner Production., 14, 1276-1285.

Schaltegger, S., \& Burritt, R. (2006). Corporate Sustainability Accounting. A Catchphrase for Compliant Corporations or a Business Decision Support for Sustainability Leaders? Sustainability Accounting and Reporting (pp. 37-59): Springer Netherlands.

Stevens, C. (2005). Measuring Sustainable Development: Statistics Brief. Paris, France.: Organisation for Economic Co-operation and Development (OECD). 


\section{Macrothink

Taplin, J. R. D., Bent, D., \& Aeron-Thomas, D. (2006). Developing a sustainability accounting framework to inform strategic business decisions: A case study from the chemicals industry. Business Strategy and the Environment, 15(5), 347-360.

Thomson, I., Grubnic, S., \& Georgakopoulos, G. (2014). Exploring accounting-sustainability hybridization in the UK public sector. Accounting, Organizations and Society, 39(6), 453-476.

United Nations Division for Sustainable Development. (2001). Environmental Management Accounting: Procedures and Principles (pp. 1). New York: United Nations.

United States Environmental Protection Agency (USEPA). (1995). An Introduction to Environmental Accounting as a Business Management Tool: Key Concepts and Terms Washington, D.C. 20460: Office of Pollution Prevention and Toxics (MC 7409). EPA 742-R-95-001.

Yang, Q. Z. (2007). Life cycle assessment in sustainable product design. SIM Technical Reports., 8(1), 57-64. 